\title{
Development of Irrigation and Its Impact on Agriculture in Punjab: 1965-66 to 2010-11
}

\author{
Dr. Pooja Rana \\ Department of Geography, Lyallpur Khalsa College Jalandhar
}

\begin{abstract}
The major purpose of the present study is to know the development of irrigation in respect of net irrigated area, Gross Irrigated area and sources of irrigation and the effects of irrigation on agriculture in respect of land use pattern, Intensity of cropping, cropping pattern and environmental degradation. For this purpose, the study is divided into two parts; first part deals with the development of irrigation and it is found that extent of irrigation has increased very significantly. It has increased from 59.72 per cent in 1965-66 to 97.9 per cent in 2010-11. The second part highlights the effects of irrigation on agriculture. These effects are noted on Net sown area, Intensity of cropping, changes in cropping pattern, yield of crops and environmental degradation. Some positive impacts are noted on net sown area, intensity of cropping and cropping pattern. On the other hand some negative impacts are noted on sub-soil water, soils and air which are badly effected. On the whole, it is observed that impacts of irrigation on Punjab agriculture are highly appreciable during the period under study.
\end{abstract}

Key Words: Net sown area, extent of irrigation, net irrigated area, gross irrigated area, intensity of cropping and environmental degradation.

\section{Introduction}

Irrigation in an agrarian economy assumes the same importance as blood in human body. It is viewed as the single most important determinant of agricultural development. It is obvious means of making the country agriculture relatively independent of vagaries of rain and of putting a more secure footing of the agricultural economy of the nation (Gadgil, 1948). It is a cultural revolution by which mankind is able to progress beyond the cruel ecological limitation set by nature to the forgoing primitive man establishing the foundation for the eventual development of civilization. Thus irrigation is an age-old device of watering the land, is defined as, "the application of water by human agency to assist of crops, grasses and trees" (Gurger, 1987). The role of irrigation in the development of agriculture is assessed in terms of changes, both quantitative and qualitative. In the post-independence period, some major developments in the pattern of irrigation have been recognized. The expansion of irrigated acreage has been substantial in Punjab as in the rest of India. Moreover, the sources and techniques of irrigation have also improved in terms of efficiency and reliability. Mechanized irrigation in form of pumping sets and tubewells have helped considerably in improving the agricultural land resources and farm production mix. It has undoubtedly been recognized that irrigation plays a prominent role in promoting higher yields and leading better productive use of agricultural land in areas of inadequate rainfall. In India, irrigation has assumed increasingly greater significance in the context of new agricultural technology (Satparthy, 1984).

Thus, irrigation has played a decisive role in agricultural development of Punjab, which has transformed from a backward agricultural economy to one of the most dynamic and progressive agricultural economies not only of India but of the whole world. In Punjab development of irrigation started in 1965-66 with the ushering of green revolution technology. It has changed agricultural scenarioland use pattern, cropping pattern, crop combinations, agricultural commercialization, intensity of cropping, crop productivity, etc.

Owing to these significant achievements, Punjab is considered as one of the most agriculturally prosperous state of India and undisputed leader in agricultural development which is largely due to adoption of modern technology by its progressive and industrious farmers. Not only positive changes but negative changes have also occurred, i.e., environmental degradation, in the main elements which have suffered the most are depletion of ground water, water pollution, air pollution, soil or land pollution, water-logging, etc.

\section{Study Area}

Punjab is situated in north-western part of India. It comprises of 1.53 per cent of total geographical area of the country. Its latitudinal extent is from $29033^{\prime} \mathrm{N}$ to $32032^{\prime} \mathrm{N}$ and longitudinal extent is from $73054^{\prime}$ ' $\mathrm{E}$ to $76050^{\prime}$ E. Punjab is land locked state but holds a great strategic significance as it is bounded by Pakistan in the West. The river Ravi forms a part of its western boundary with Pakistan. It is further bounded by Jammu and Kashmir in the north, Himachal Pradesh in the east, Haryana and Rajasthan in the south-east and south. High 
diversity is found in its physical environment, i.e. north and north-east parts having hills and rough topography, while southern parts are having frequent occurrences of sand dunes. Whereas flood plains run along the rivers Ravi, Beas, Satluj and Ghagger subjected to floods every year.

\section{Purpose and Methodology}

Present study is intended to evaluate the major impacts of irrigation on agriculture during 1965-66 to 2010-11. For the present study the adopted methodology is consonance with selected objectives. It includes processing, analysis and synthesizing of the relevant data obtained from secondary sources. District has been taken as unit of study. Four time periods have been taken i.e. beginning of year of green revolution (1965-66), post green revolution (1985-86), 2005-06 and the recent 2010-11 for showing the spatial pattern of development of irrigation and its impacts on agriculture. Statistical techniques are used for deriving the results.

\section{Development of Irrigation}

With the advent of new agricultural technology, especially its biochemical component, importance of irrigation as a key element in agricultural development has further increased. Irrigation is an important component of the new technology package, and promotes the use of other inputs in the package like fertilizers, insecticides, pesticides, weedicides and H.Y.V of seeds

Table: 1 Changes in Irrigation in Punjab during 1965-66 to 2010-11

\begin{tabular}{|c|c|c|c|c|}
\hline Year & $\begin{array}{c}\text { Net Irrigated } \\
\text { Area (Ha.) }\end{array}$ & $\begin{array}{c}\text { Gross Irrigated Area } \\
\text { (Ha.) }\end{array}$ & $\begin{array}{c}\text { Extent of Irrigation (per } \\
\text { cent) }\end{array}$ & $\begin{array}{c}\text { Number of Tubewells (in } \\
\text { Lakhs) }\end{array}$ \\
\hline $1965-66$ & 2567.1 & 3516.6 & 59.72 & 967.7 \\
\hline $1985-86$ & 3749.3 & 6628.6 & 87.55 & 2265.9 \\
\hline $2005-06$ & 4060.0 & 7679.7 & 97.4 & 2914.6 \\
\hline $2010-11$ & 4074.0 & 7722.9 & 97.9 & 3124.8 \\
\hline
\end{tabular}

Source; Economic and Statistical Organization of Punjab, Chandigarh.

Figure: 1

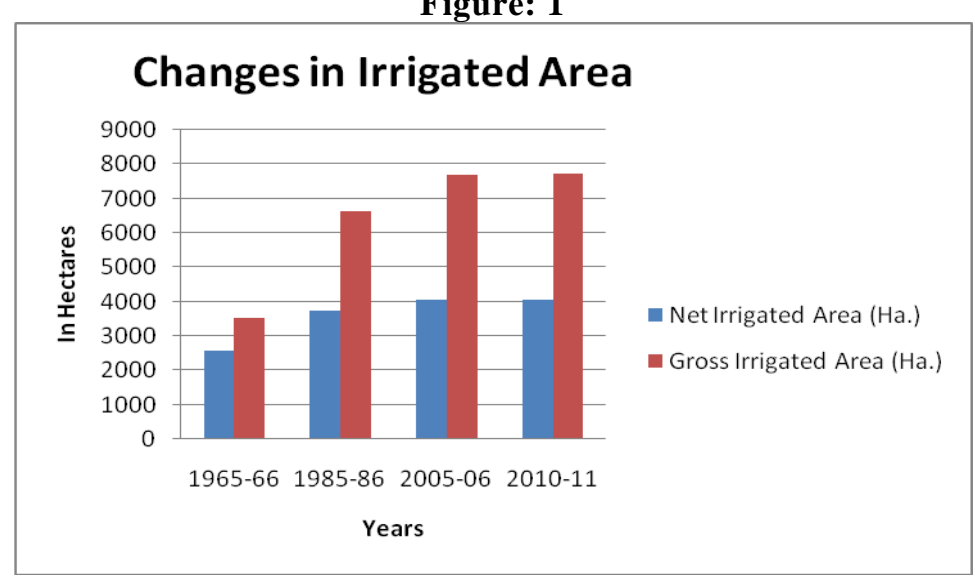

Source; Economic and Statistical Organization of Punjab, Chandigarh.

Figure: 2

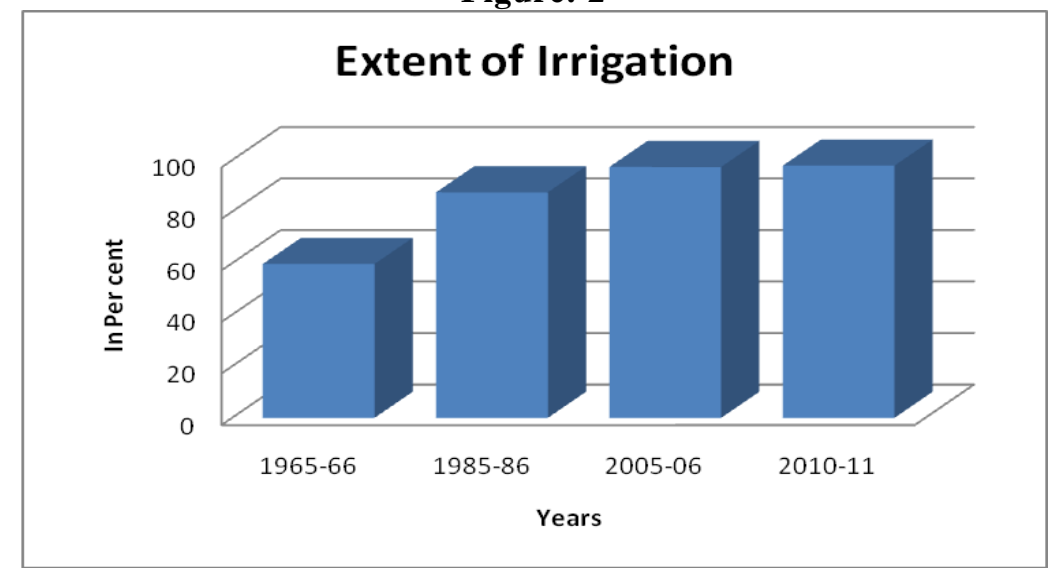

Source; Economic and Statistical Organization of Punjab, Chandigarh. 
As a result, drastic changes have been recorded in irrigation. Punjab has taken significant strides in the process of irrigation development since 1965 which is very clearly indicated that area under net irrigation from all sources was 2567.1 hectares in 1965-66. It has increased to 4074 hectares in 2010-11 and registered a positive volume of change of 1506.9 hectares which looks quite impressive. But in

\section{Figure:3}

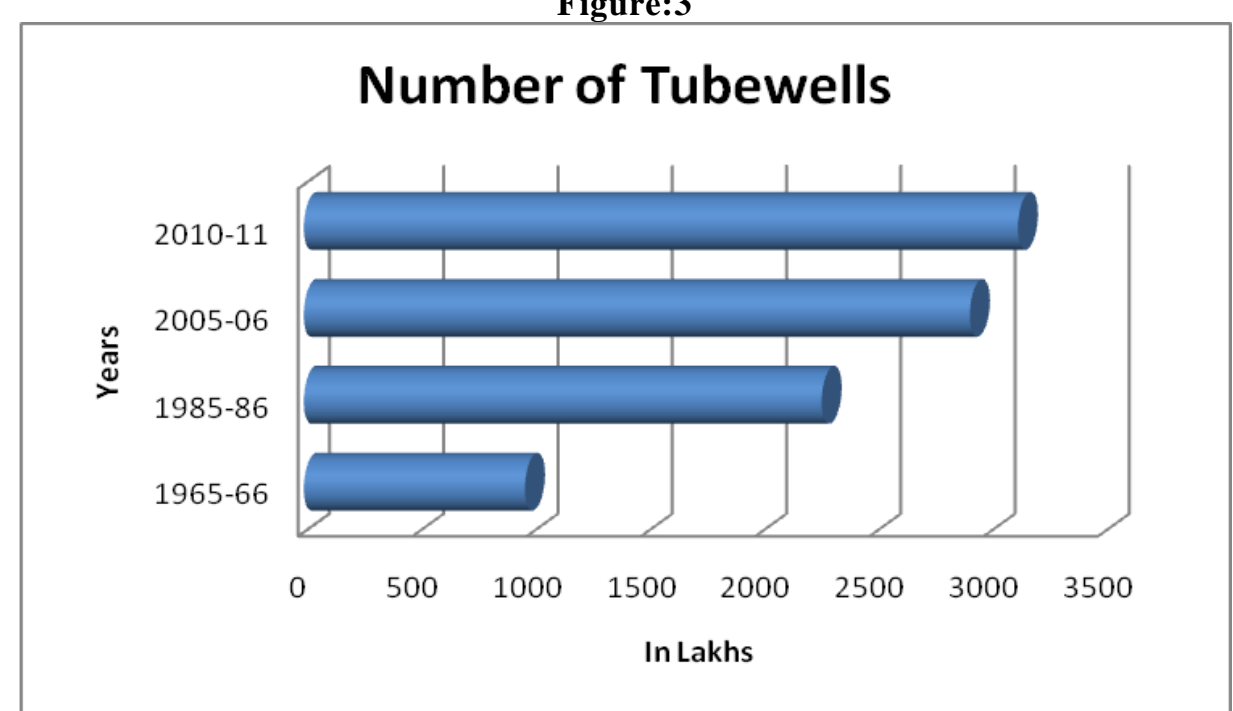

Source; Economic and Statistical Organization of Punjab, Chandigarh.

respect of gross irrigated area, it has increased from 3516.6 hectares in 1965-66 to 7722.9 hectares in 2010-11 and this way positive increase of 4206.3 hectares is recorded during study period. But the overall extent of irrigation has increased from 59.72 per cent in 1965-66 to 97.9 per cent in 2010-11. On the whole positive volume of change of 38.18 per cent is recorded during 1965-66 to 2010-11. Thus there is only 5 per cent of net sown area remain unirrigated. This significant positive change is the result of extension in canal irrigation and sinking of tubewells on large scale. The number of tubewells which was 967.7 in 1965-66 has increased in 2265.9, 2914.6 and 3124.8 during 1985-86, 2005-06 and 2010-11 respectively. the rapid increase in number of tubewells is largely the result of development in electricity, liberal loan facilities for sinking of tubewells to farmers and the introduction of the pivots of green revolution technology such as the use of chemical fertilizers, HYV of seeds, insecticides, pesticides, weedicides, etc. thus the development state of irrigation has made feasible the transformation of Punjab agriculture.

\section{Impact of Irrigation on Agriculture}

The effects of developed irrigation on agriculture in Punjab are consist of (a) Landuse Pattern; (b) Changes in cropping pattern; (c) Intensity of cropping; (d) environmental Degradation.

\section{(A)Land Use Patterns}

Due to development of irrigation, some categories of land use have gained area, whereas some have lost. Because, development of irrigation made feasible the reclamation of waste land, increase in net sown area, decline in fallow and current fallow land. Net sown area has increased from 75.7 percent to 82.6 percent and 82.9 percent to 83.1 per cent during 1965-66, 1985-86, 2005-06 and 2010-11 respectively. Whereas Area under Forest is 1.7 percent, 5.1 percent, 5.7 percent, 5.8 per cent of the total reporting area during 1965-66, 1985-86, 2005-06 and 2010-11 respectively and recorded an positive volume of change of 4.0 percent during study period. Non agricultural land has increased from 6.5 per cent to 9.0 per cent, 9.6 percent and 10.0 per cent of the total reporting area during 1965-66, 1985-86, 2005-06 and 2010-11 respectively. Area under Barren Land has reduced from 8.3 per cent to 1.3 per cent, 0.5 per cent and 0.2 per cent of the total reporting area during 196566, 1985-86, 2005-06 and 2010-11 respectively. Whereas, Fallow land has decreased from 4.9 per cent in 196566 to 1.8 per cent in 1985-86 and 1.1 per cent in 2005-06 to 0.07 per cent in 2010-11. In case of culturable waste land, it has declined from 2.0 per cent to 0.7 per cent and 0.2 per cent to 0.07 per cent of total reporting area during period under present investigation. The major causes of decline in cultivable waste land are development of irrigation and reclamation of waste land, extension of net sown area and area sown more than once. 
Table: 2 Changes in Land Use Pattern in Punjab during 1965-66 to 2010-11

\begin{tabular}{|l|l|l|l|l|}
\hline Land use & $1965-66$ & $1985-86$ & $2005-06$ & $2010-11$ \\
\hline Forest Land & 1.7 & 5.1 & 5.7 & 5.8 \\
\hline Barren Land & 8.2 & 1.3 & 0.5 & 0.2 \\
\hline Non-Agricultural Land & 6.5 & 9.0 & 9.6 & 10.0 \\
\hline Culturable waste Land & 2.0 & 0.7 & 0.2 & 0.07 \\
\hline Fallow Land & 4.9 & 1.8 & 1.1 & 0.07 \\
\hline Net Sown Area & 75.7 & 82.6 & 82.9 & 83.1 \\
\hline
\end{tabular}

Source; Economic and Statistical Organization of Punjab, Chandigarh.

Figure:4

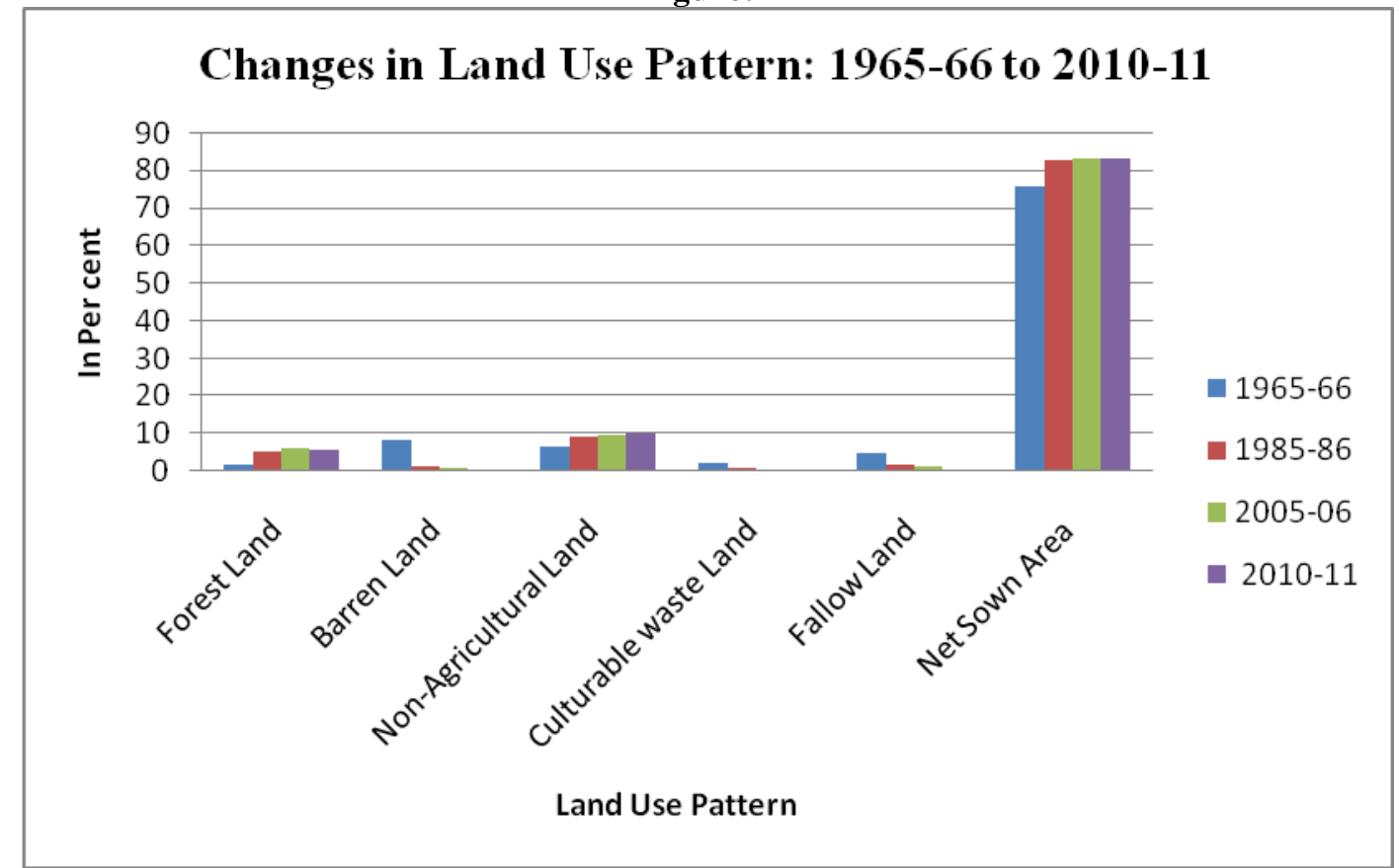

Source; Economic and Statistical Organization of Punjab, Chandigarh.

\section{(B) Intensity of Cropping}

The next important impact of irrigation in Punjab is on intensity of cropping. Because development of irrigation makes possible the adoption of short duration of HYVs of crops, use of chemical fertilizers, insecticides, pesticides, weedicides, etc. and as a result farmers grow two or three crops in one agricultural year. The index of intensity of cropping has improved from 127.2 per cent in 1965-66 to 171.4 per cent in 1985-86 and further to 188.7 percent in 2005-06 to 189.5 per cent in 2010-11. It shows that state has recorded 62.3 per cent positive volume of change during study period.

Table: 3 Changes in Intensity of Cropping in Punjab: 1965-66 to 2010-11

\begin{tabular}{|c|c|}
\hline \multicolumn{2}{|c|}{ (In per } \\
\hline year & Intensity of Cropping \\
\hline $1965-66$ & 127.2 \\
\hline $1985-86$ & 171.4 \\
\hline $2005-06$ & 188.7 \\
\hline $2010-11$ & 189.5 \\
\hline
\end{tabular}

Source: Economic and Statistical Organization of Punjab, Chandigarh. 


\section{Figure:5}

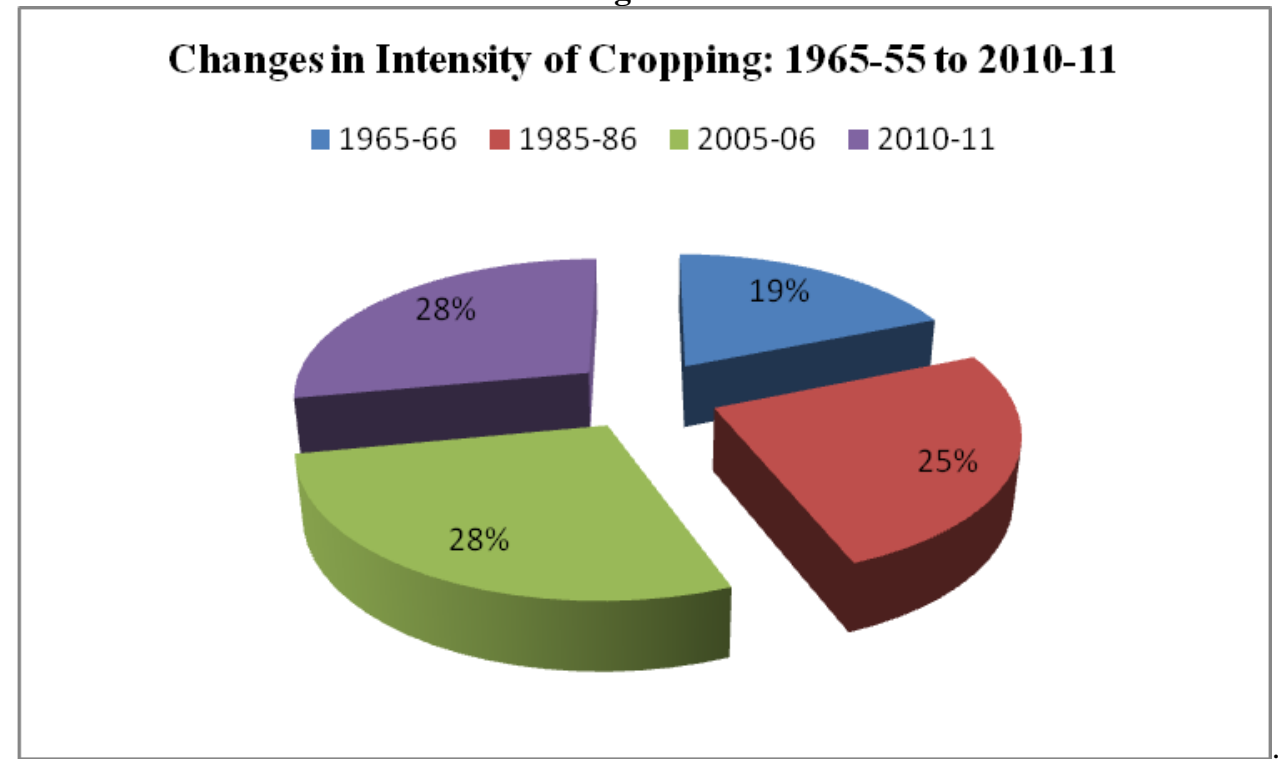

Source: Economic and Statistical Organization of Punjab, Chandigarh.

\section{(C) Cropping Pattern}

The next important impact of irrigation in Punjab is seen on its cropping pattern. With the adoption of green revolution technology, the significant ups and downs are recorded in areas under different crops. Some crops have either emerged or disappeared from agricultural landscape in Punjab. Low water resistant crops like grams, pulses, oilseeds, etc. have lost area very significantly, whereas crops like wheat, rice, etc. have gained area under their cultivation.

Wheat crop has experienced 13.1 percent to 0.3 percent and 13.4 percent to 0.43 positive volume of change during 1965-66 to 1985-86, 1985-86 to 2005-06 and 2005-06 to 2010-11 respectively. After wheat, rice is the second most important crop of the study region, which has witnessed positive volume of change of 18.8 percent, 9.4 percent and 2.25 per cent during 1965-66 to $1985-86,1985-86$ to 2005-06 and 2005-06 to 2010-11 respectively. The most important crop of negative volume of change is noted gram. Its area has declined from 9.8 per cent in 1965-66 to 1.4 per cent in 1985-86 and further declined to 0.05 percent in $2005-06$ to 0.03 per cent in 2010-11 and consequently recorded 9.7 percent overall negative volume of change during study period, which is largely the result of development of irrigation, introduction of HYVs of wheat, higher and assured economic returns from wheat as compared to gram, etc. Second looser crop is noted maize which has declined from 7.7 per cent in 1965-66 to 1.68 per cent in 2010-11. Cotton crop has experienced 1.2 per cent, 0.7 per cent and 0.88 per cent negative volume of change during 1965-66 to 1985-86, 1985-86 to 2005-06 and 2005-06 to 2010-11 respectively. In case of Sugarcane an overall negative volume of change of 2.42 percent is recorded during 1965-66 to 2010-11 in the study region. Oilseeds have registered 2.0 per cent, 1.4 per cent and 0.09 per cent overall negative volume of change during 1965-66 to 1985-86, 1985-86 to 2005-06 and 2006-06 to 2010-11 respectively. While, pulses have also experienced overall negative volume of change of 10.9 per cent during 1965-66 to 1985-86, 2.2 per cent during 1985-86 to 2005-06 and 0.47 per cent during 2005-06 to 2010-11. Fodder crops have declined from 14.7 per cent

Table: 4 Changes in Cropping Pattern in Punjab: 1965-66 to 2010-11

\begin{tabular}{|l|l|l|l|l|}
\multicolumn{1}{|c|}{ (In per cen } \\
\hline Crops & \multicolumn{1}{|c|}{$1965-66$} & $1985-86$ & $2005-06$ & $2010-11$ \\
\hline Rice & 5.4 & 24.2 & 33.6 & 35.85 \\
\hline Wheat & 30.7 & 43.8 & 44.1 & 44.53 \\
\hline Grams & 9.8 & 1.4 & 0.05 & 0.03 \\
\hline Maize & 7.7 & 4.2 & 1.9 & 1.68 \\
\hline Cotton & 8.9 & 7.7 & 7.0 & 6.12 \\
\hline Sugarcane & 3.3 & 1.4 & 1.1 & 0.88 \\
\hline Pulses & 13.4 & 2.5 & 0.3 & 0.21 \\
\hline Oilseeds & 4.2 & 2.2 & 0.8 & 0.33 \\
\hline Fodder & 14.7 & 12.2 & 8.8 & 7.9 \\
\hline Other crops & 3.1 & 1.9 & 1.7 & 1.6 \\
\hline
\end{tabular}

Source: Economic and Statistical Organization of Punjab, Chandigarh. 
Figure:5

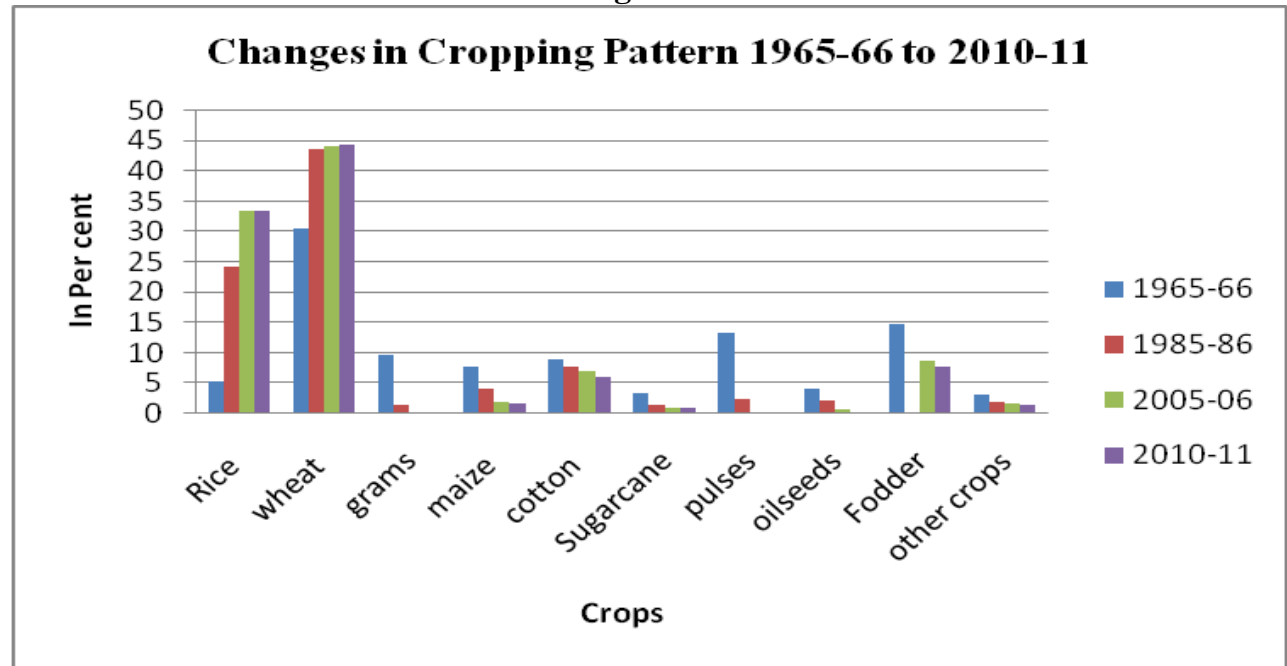

Source: Economic and Statistical Organization of Punjab, Chandigarh.

in 1965-66 to 12.2 per cent in 1985-86 and further decreased to 8.8 percent in 2005-06. Thus, overall negative volume of change of 6.8 per cent is recorded during 2005-06 to 2010-11.

All these facts show that there is remarkable shift in cropping pattern of Punjab during the study period due to the development of irrigation. In other words, one can say that Punjab cropping pattern have changed from highly diversified to highly specialized owing to development of irrigation which helps the adoption of green revolution technology.

\section{(D) Environmental Degradation}

Due to development of irrigation facilities in Punjab, environment is getting degraded. Main elements which suffered the most are soil, water and air.

(1) Soils - Development of canal irrigation has affected the soils in south-western parts of Punjab due to excessive canal irrigation, the water table has come closer to the surface along with impurities and ultimately caused water logging. When these water logging areas have drained out, the fluorides lying on upper layer of surface remained on the earth surface which caused salinity and alkanity. Moreover, the adoption of HYV of seeds becomes possible due to the development of irrigation facilities which require heavy doses of chemical fertilizers. As a result, these agro-chemicals have contaminated the soils. Moreover wheat-rice crop rotation has depleted both macro and micro nutrients of soils and as a result soils become redundant. Thus to get high yields per unit area farmers have to make the application of chemical fertilizers. Even the preparation of the field for rice sowing have also affected the soil structure. All this combinedly led to degradation of soils health.

(2) Sub-soil water- Irrigation has also affected the aquifers of sub-soil water. Increased crop intensity and wheat-rice crop rotation have highly pressurized on sub-soil water, because wheat and rice crop require frequent watering. The increased demand of water has met by sinking of large number of tubewells. Thus the exploitation of the sub-soil water was so heavy that recharge could not keep pace with the rate at which it was pumped out and as a result, the water table has declined upto 100 feet in central parts of Punjab. Whereas, development of irrigation in Punjab made possible the use of chemical fertilizers, insecticides, pesticides, etc. on large scale and has polluted sub-soil water. The excessive canal irrigation in the south-western parts of the state where sub-soil water is saline and alkaline has come up to the surface and caused water logging conditions, which again affect the soils.

c) Air Pollution - The use of diesel pumping sets, burning of paddy and wheat straw in the fields, spraying of agro-chemicals, etc. are the major causes of air pollution in the state. Moreover the use of heavy vehicles for the movements of outputs from fields to markets have also caused air pollution.

\section{Conclusion and Suggestions}

The study is concluded that the overall extension of irrigation facilities have led to the extension of net sown area, intensification of land use, changes in cropping pattern and increase in agricultural production. Whereas, due to the over use of irrigation facilities, negative effects of irrigation are also registered on the subsoil water and soil chemistry of Punjab. With the development of irrigation, Punjab becomes the leading agricultural state of India. But now a days, due to the over use of irrigation facilities Punjab state is facing certain serious problems. Therefore, for further development of agriculture, it becomes imperative to make some suggestions, such as; 
a) The excessive use of pumping sets should be discouraged for the future growth of agriculture by using efficient techniques like sprinkle irrigation, drip irrigation and development of under ground water channels.

b) Farmers should be educated and encouraged to grow water resistant crops i.e. Maize, Basmati rice, oilseeds, pulses, etc.

c) Sprinkle and drip irrigation should be encouraged along the Shiwaliks and in the south-western parts of Punjab.

d) There should be judicious use of chemical fertilizers so that sub-soil water, soils and agricultural produce should not be contaminated.

e) Considerable areas about 30 per cent should be diverted to other crops like maize, fodder, oilseeds, pulses, etc. from wheat-rice crop rotation.

f) Minimum support price should be fixed for crops like maize, vegetables, oilseeds, pulses, fruits, etc. which will certainly encourage the farmers to bring more area under these crops.

If all these suggestions are taken into account in the study region than Punjab agriculture can become economical viable, free from environmental degradation and sustainable for the time to come.

\section{References}

[1]. Economic and Statistical Organization of Punjab, Chandigarh.

[2]. Gadgil, D.R. (1948), "Economic Effect of Irrigation”, Gokhle Institute of Politics and Economics, Poona, p.18.

[3]. Gurjar, Ram Kumar (1987), "Irrigation for Agricultural Modernization ”, Scientific Publisher, Jodhpur, p.1.

[4]. Satparthy, T. (1984), "Irrigation and Economic Development", Ashish Publishing House, New Delhi, pp.1-2. 